\title{
An Analysis of State-Owned Enterprise Holding Company Formation: The Case of Printing and Media Companies
}

\author{
Ihsan Nasihin \\ Perusahaan Umum Percetakan Uang Republik Indonesia \\ Harry Suharman \\ Faculty of Economics and Business \\ Universitas Padjadjaran \\ Sofik Handoyo \\ Faculty of Economics and Business \\ Universitas Padjadjaran
}

\begin{abstract}
This research aims to analyze the process of forming a holding company of state-owned enterprises in the printing and media business. This research uses qualitative research methods with a case study approach. The results of the study indicate that there are three options for printing and media holding company. The first option is printing and media holding with Perum Peruri as the holding company that will oversee four companies, namely Perum LKBN Antara, Perum PNRI, PT Balai Pustaka (Persero), and Perum PFN. The second option is printing holding and media holding. In printing holding, the holding company is Perum Peruri which will oversee one company, namely Perum PNRI. In media holding, the holding company is Perum LKBN Antara which will oversee two companies, namely PT Balai Pustaka Persero and PFN Public Corporation. The third option is the printing and media holding company with Perum LKBN Antara as a holding company that will oversee three companies, namely Perum PNRI, PT Balai Pustaka (Persero), and Perum PFN. At the same time, Perum Peruri will stand alone. The analysis indicates that the second option is the most appropriate in terms of logical roadmap and holding characteristics since printing (security printing) and media (distribution news) business are two distinct types of businesses.
\end{abstract}

Keywords: Holding company, State-owned enterprises, Qualitative research, Case study, Stand-alone

\section{Introduction}

Digital disruption is one of the threats faced by organizations in today's business environment. Digital disruption is an era in which technological advances have posed threats (Heriyanto, 2018). This threat is marked by a large number of people who use technology in their daily activities (Bashori, 2018). Digital disruption takes place in various aspects and levels, ranging from individuals, working conditions, business practices, industrial structures, and societies (Heriyanto, 2018). The emergence of millennial societies that adopt high technology has led to the development of numerous technologies and management policies to establish novel business processes to thrive in their current state and grow in the future (Christensen, Raynor, Rory, \& McDonald, 2015).

The stages of digital business disruption can be observed from two perspectives, i.e. in terms of business and technological development. From a technological development perspective, the business world has now entered the era of Industry 4.0, where many business processes are focused on digitalization (Hamdan, 2018). Industrial revolution 4.0 focuses primarily on simplifying market penetration or the shared economy (Pangaribuan \& Kawiworo, 2019). It can be identified in the short cycle of product innovation and production processes carried out by the company (Sijabat, 2019). In Indonesia, for example, the rise of online applicationbased transportation services such as Grab and 
Gojek lead to a further decline in conventional taxi businesses and other transportation services (Prihatin, 2016). Not only are transportation systems impacted by digital disruption, the increasing 'outbreak' of online shopping in society, contributing to the closure and underperformance of many companies in the retail sector (Utami, 2018).

The growth of the Industrial Revolution 4.0 also affected state-owned companies, including state-owned printing and media companies. The industrial revolution era has also affected the Public Enterprise for Banknotes Printing and Minting of the Republic of Indonesia (Perum Peruri), the Government Printing Office of the Republic of Indonesia (Perum PNRI), the Antara National News Agency (Perum LKBN Antara), PT Balai Pustaka (Persero), and the State Film Production Company (Perum PFN). This fact can be seen in Figure 1 below
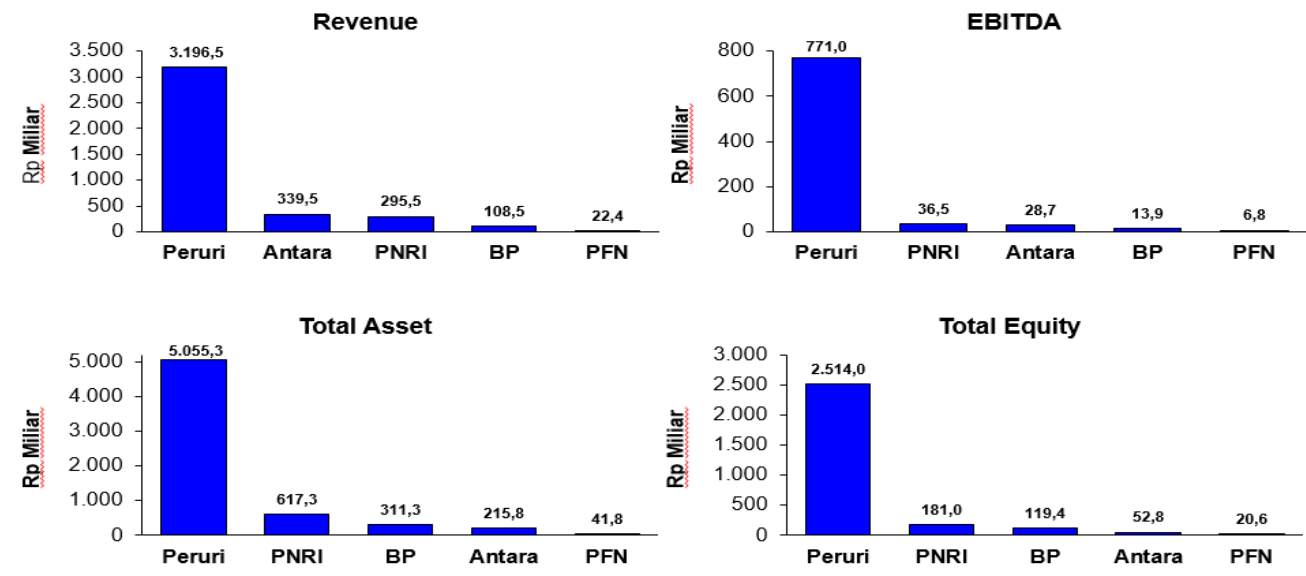

Figure 1. Financial performance of Printing and Media SOEs

Based on the financial performance shown in Figure 1 above, it can be identified that only Public Enterprise for Banknotes Printing and Minting of the Republic of Indonesia (Perum Peruri) indicate an excellent financial performance compared with other five state-owned companies in the printing and media business. It occurs due to the increasing cashless and paperless transactions, cybersecurity, big data, smart chips, digital content, e-books, e-learning, and the tendency of people to use technology for business or online transactions (Sigar, 2016). Eventually, the use of cashless and digital goods in Indonesia has not significantly affected the printing and media industry, but it is likely to have a considerably substantial effect on the printing and media sector over the next few years (Ayudya \& Wibowo, 2018). Although the printing and media business in Indonesia may continue to survive, the increasingly widespread use of cashless and digital products in the future can affect the performance of printing and media companies (Karman, 2017).
The government, through the Ministry of State-owned Enterprises, has compiled a road map for the Ministry of State-owned Enterprises in 2014-2019. The plan is to establish several state-owned holding companies in the same business sector. Based on the 2014-2019 roadmap of the Ministry of State-owned Enterprises, one of the plans is to establish a printing and media holding. Perum Peruri is assigned and appointed by the Ministry of State-owned Enterprises as a holding company and become a shareholder of other four state-owned enterprises namely the Public Enterprise for Banknotes Printing and Minting of the Republic of Indonesia (Perum Peruri), the Government Printing Office of the Republic of Indonesia (Perum PNRI), the Antara National News Agency (Perum LKBN Antara), PT Balai Pustaka, and the State Film Production Company (Perum PFN).

There are several obstacles during the plan to set up state-owned printing and media holdings, including the declining performance of prospective subsidiaries due to the impact of 
digital disruption (Heriyanto, 2018). In order to compete in the current industrial era 4.0, prospective subsidiaries must immediately undertake a business transformation (Putra \& Gede, 2019). Indonesia Ministry of Stateowned Enterprises, therefore, planned that state-owned companies with the same business sectors would not compete with each other but would collaborate and synergize.

\section{Literature Review}

\section{Institutional Theory}

The institutional theory refers to the arrangement of the holdings. Organizations use Institutional theory to thrive and persuade the public that the company is a legitimate body and that it deserves support (Meyer, 2007). In the perspective of institutional sociology, organizational compliance with the environment can make organizations similar to one another or referred to as the process of 'isomorphism' (Dimaggio \& Powell, 2012). There are three mechanisms for isomorphic institutional transition, i.e. mimetic isomorphism (as a result of uncertainty response), normative isomorphism (as a result of professionalization), and coercive isomorphism that originates from the issue of legitimacy (Dimaggio \& Powell, 2012).

Mimetic isomorphism relates to the process of forming the printing and media holding. Indonesia Ministry of State-owned Enterprises, as the capital owner, performs benchmarks and lessons learned from various existing holdings. Normative isomorphism in the formation of printing and media holding occurs when the Ministry of State-owned Enterprises seeks to generate value-added creation from business synergies in the printing and media industries between state-owned companies. Coercive isomorphism in the formation process of printing and media holding is a government action to force stateowned enterprises forming holding company as stated as in strategic plan for the period of 20152019.

\section{Change of Management Theory}

Change of management theory is a systematic approach to assist individuals and organization teams in coordinating a transition from existing conditions to preferably new conditions
(Kitchen \& Daly, 2002). An organizational transition is an act of moving an entity from the present circumstances to the future circumstances that are expected to maximize efficiency (Harminingtyas, 2010). Based on Indonesia Government Regulation No. 72 of 2016, it requires the Ministry of State-owned Enterprises to make reforms to boost the competitiveness of state-owned companies in order to deal with the global economy by restructuring state-owned enterprises. Three steps need to be accomplished in order to make organizational changes, namely the unfreezing stage, moving stage and refreezing stage (Kaminski, 2011):

In the unfreezing stage, the merger process may be carried out by state-owned companies in the printing and media business. In the moving stage, the process of studying a printing and media holding formation poses many possibilities or design initiatives or organizational frameworks for a printing and media holding. Meanwhile, in refreezing stage, it is anticipated that the establishment of printing and media holding would shape business synergy or business balance for each member of printing and media holding, thus increasing efficiency and effectiveness of stateowned printing and media companies so that it can generate value-added to growth.

Other scholars argue that three stages must be undertaken in making organizational changes, namely the input approach, the process approach and output approach (Permanasari \& Surya Perdhana, 2017). Input approach, the Ministry of State-owned Enterprises undertakes a process of change for state-owned companies, beginning with the preparation of the roadmap for 2014-2019 and subsequently drawing up a strategic plan for the Ministry of State-owned Enterprises in 20152019 , one of which is to form the concept of National Holding Company through one of the stages of creating a holding in the printing and media sector. Process approach, there are several components to adjust the elements of the target transition, the process of forming a printing and media holding, including financial aspects and non-financial aspects. Finally, output approach, the process of forming a printing and media holding is expected to generate value-added development in the printing and media business sector for state- 
owned companies so that they can compete on the global arena.

\section{Resource-based Theory}

The resource-based theory concerns the relationship between the resources of the company and its competitive advantage in the industry (Jay, 1991). Companies may achieve competitive advantage and sound financial performance by owning, controlling, and using their strategic assets (Wernerfelt, 1984). If a company can make efficient use of its resources, it is possible to have a competitive advantage and compete with its rivals (Prasetya \& Siti, 2011). The competitive advantage achieved if the organization can manage and utilize its resources effectively and efficiently (Widyaningdyah \& Aryani, 2013). Company resources that can achieve competitive advantage are valuable, scarce, inimitable, and irreplaceable resources (Purnomo, 2011).

The concept of business synergy in the process of forming a printing and media holding is by establishing business clusters and merging state-owned companies with related business or similar business fields, as well as restructuring in order to achieve the optimal number of state-owned companies. It is a mandate of presidential instruction No. 5 of 2008, regarding a restructuring of state-owned companies through five measures, namely stand-alone, merger or consolidation, holding, divestment, and liquidation. Table 1 shows the five restructuring measures along with its characteristics:

Table 1. Restructuring Characteristics or Actions of State-owned Companies

\begin{tabular}{|c|c|}
\hline Restructuring Form & Characteristics \\
\hline Stand alone & $\begin{array}{l}\text { 1. A relatively large market share and contains a security element. } \\
\text { 2. Single-player/ the leading player. } \\
\text { 3. No potential to be merged or held. } \\
\text { 4. The existence is based on applicable laws and regulations, and generally a } \\
\text { captive market. }\end{array}$ \\
\hline $\begin{array}{l}\text { Merger / } \\
\text { consolidation }\end{array}$ & $\begin{array}{l}\text { 1. Similar in terms of business types and market segments. } \\
\text { 2. High competition. } \\
\text { 3. The government owns the majority of shares. } \\
\text { 4. Poor performance. } \\
\text { 5. Going concerned is uncertain, but it also has the potential to be merged with } \\
\text { other state-owned companies. }\end{array}$ \\
\hline Holding & $\begin{array}{l}\text { 1. Similar business sector } \\
\text { 2. Different types of businesses and market segments } \\
\text { 3. High competition } \\
\text { 4. There are still prospects or prospective businesses } \\
\text { 5. The government is the majority owner }\end{array}$ \\
\hline Liquidation & $\begin{array}{l}\text { 1. No Public Service Obligation (PSO) and non-"strategic" (not necessarily } \\
\text { maintained state-owned status) } \\
\text { 2. Suffered losses in several years } \\
\text { 3. High business competition } \\
\text { 4. Low externality } \\
\text { 5. Not prospective business } \\
\text { 6. Negative equity }\end{array}$ \\
\hline Divestment: & $\begin{array}{l}\text { 1. Limited Liability Company. } \\
\text { 2. Being in a competitive business or industrial sector or rapidly changing } \\
\text { technological elements. } \\
\text { 3. The line of business, according to the law, does not explicitly have to be } \\
\text { managed by state-owned enterprises. } \\
\text { 4. Not engaged in the defence and security sector. } \\
\text { 5. Not managing natural resources } \\
\text { 6. Not undergoing certain sectors by the government which are given specific tasks } \\
\text { to carry out certain activities related to community interests. } \\
\text { 7. Comply with capital market regulations if privatization is carried out through } \\
\text { the capital market. }\end{array}$ \\
\hline
\end{tabular}

Source: The Ministry of State-owned Enterprises of the Republic of Indonesia (2009) 


\section{The method, Data and Analysis}

\section{Research Design}

This research is carried out in the printing and media industry on state-owned enterprises. The methodology used for the research is the interpretive analysis paradigm. The research is conducted by using a qualitative research method with a case study approach. Two types of data sources are used, i.e. primary and secondary data. Primary data is generated from interview transcripts and reports from direct observations in each company in the printing and the media sector, i.e. Public Enterprise for Banknotes Printing and Minting of the Republic of Indonesia (Perum Peruri), the Government Printing Office of the Republic of Indonesia (Perum PNRI), the Antara National News Agency (Perum LKBN Antara), PT Balai Pustaka, and the State Film Production Company (Perum PFN). Whereas the secondary data used is in the form of annual reports, financial reports, news from the official website about state-owned companies in the printing and media sector, including the official website of the Ministry of State-owned Enterprises, published books, research papers, and other relevant documents.

Fieldwork and library research are two methods were used for collecting data.
Fieldwork was carried out by conducting an interview, observation, and document review. Document review was performed by reviewing the records of secondary sources of information. Several informants involved in the process of forming a printing and media holding were interviewed using an in-depth semi-structured interview approach. Observations were conducted to obtain a point of view of the formation of printing and media holding. The types of observations used are uncontrolled observational studies and participant observation. Participant observation is carried out through the researcher directly participating in the activity. Participant observation is an approach that is often used in case study research. Library research is conducted by evaluating relevant secondary data, as well as evaluating annual reports, official website news of state-owned companies in the field of printing and media, including the official website of the Ministry of State-owned Enterprises, published research journals and books.

The data analysis technique is required to analyze the research data. The methodology used for data analysis is qualitative data analysis with an integrated model consisting of four primary subjects (Matthew, Michael, \& Johnny, 2014):

Figure 2. Miles and Hubberman's Interactive Model Data Analysis Component

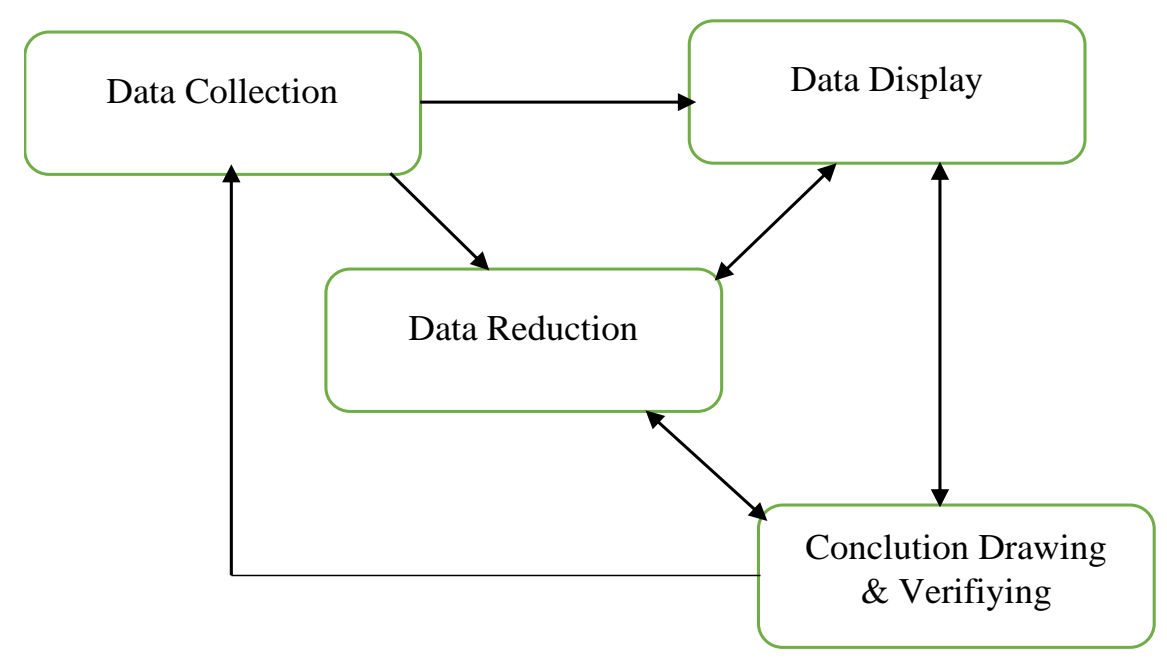

Source: Matthew et al., 2014 


\section{Data collection, reduction and Display}

The collection of data is conducted by observation, interview and reporting, and then documented in field notes. The field observations can be in the form of observations of explanation and reflection notes. Description note is written in the form of interview output. Whereas, reflection notes are notes which include additions or suggestions. Description notes and reflection notes can be obtained through several competent speakers who know about the problem under study, i.e. digging up information related to the analysis of printing and media holding formation is required for this research.

Data reduction is conducted by selecting data related to the discussion or subject being performed and based on the theory and research focus. The focus of research is to determine if developing the printing and media holdings is feasible or inappropriate. Data presentation is carried out by presenting a summary of the data obtained via the triangulation process from data reduction. Observation and interviews should be performed in the process of triangulation to prevent bias in the analysis of the results.

\section{Conclusion Drawing \& Verifying}

The data that has been collected is linked by comparing it with one another so that conclusions can be drawn easily. The conclusion of the study of printing and media holding and its feasibility studies can be obtained after conducting the method of presenting data to obtain the research results. Triangulation is a commonly used technique to test the validity and reliability of data in qualitative research (Sekaran \& Bougie, 2016). Triangulation means research findings are more compelling if different sources and methods are used to infer the same findings. Several forms of triangulation include (1) method triangulation - conducted using several methods of data collection or data analysis. By using two types of data collection methods, namely field research and library research; (2) data triangulation - conducted by collecting data from several different sources and those who are competent with the research problem and topic; (3) researcher triangulation - carried out to collect or analyze data simultaneously. The data analysis process is carried out to prevent bias in interpreting the research data; (4) theory triangulation - conducted by using several theories or perspectives to interpret or explain data by using three theories as approaches to interpreting data, namely institutional theory, the theory of change of management, and resource-based theory.

\section{Result and Discussion}

The process of forming a printing and media holding is carried out based on shareholder action. Aligned with the 2014-2019 Roadmap of the Ministry of State-owned Enterprises of the Republic of Indonesia, one of the contents of the roadmap is to continue the concept of the National Holding Company by forming a stateowned organization in the form of a super holding company. The Ministry of State-owned Enterprises formed six holding companies with similar business sectors as a first step in the formation of super holdings. The six sectors include mining, oil and gas, housing, toll roads, financial services and food. The process of establishing state-owned enterprise holdings in the printing and media sector is relevant to Government Regulation No. 72 of 2016. Several implications of the formation to the Government Regulation is illustrated in Table 2 below:

Table 2. The relevance of Government Regulation No. 72 of 2016

\begin{tabular}{|c|c|c|}
\hline Article & Des & Implic \\
\hline Arti & $\begin{array}{l}\text { Paragraph 1: State-owned enterprises are } \\
\text { business entities whose entire or most of the } \\
\text { capital is owned by the state through direct } \\
\text { investments derived from separate State assets. }\end{array}$ & \multirow{2}{*}{$\begin{array}{l}\text { Based on Article 1 (1), in } \\
\text { the proses of forming a } \\
\text { holding, the state continues } \\
\text { to make capital investments } \\
\text { directed towards the parent } \\
\text { company; therefore it can }\end{array}$} \\
\hline $\mathrm{Al}_{1}$ & $\begin{array}{l}\text { Sources of State Capital Inclusi } \\
\text { from the State Revenue and Exp }\end{array}$ & \\
\hline
\end{tabular}




\begin{tabular}{|c|c|c|c|}
\hline & & $\begin{array}{l}\text { shall include State assets in the form of a. fresh } \\
\text { funds; b. State property; c. State receivables } \\
\text { from State-owned Enterprises or Limited } \\
\text { Liability Company; d. state-owned shares in } \\
\text { State-owned Enterprises or Limited Liability } \\
\text { Company; and/or e. other state assets. }\end{array}$ & \multirow[b]{2}{*}{$\begin{array}{l}\text { be concluded that holding } \\
\text { parent is a state-owned } \\
\text { enterprise. } \\
\text { Based on Article 1 (1), } \\
\text { Article 2 (2) and Article 2A } \\
\text { (2), in the proses of forming } \\
\text { a holding, State transfer } \\
\text { capital investments in a } \\
\text { state-owned company or } \\
\text { Limited Liability Company } \\
\text { (holding member) to } \\
\text { another state-owned } \\
\text { company (holding parent), } \\
\text { therefore holding member is } \\
\text { a subsidiary of state-owned } \\
\text { enterprise. } \\
\text { Based on Article 2A (2), } \\
\text { state still owns share with } \\
\text { privilege in the state-owned } \\
\text { enterprise subsidiaries. } \\
\text { Based on Article } 2 \mathrm{~A} \text { (7), } \\
\text { subsidiaries is treated the } \\
\text { same as state-owned } \\
\text { enterprises including in } \\
\text { terms of obtaining } \\
\text { Government assignment or } \\
\text { conducting general services } \\
\text { as well as obtaining State or } \\
\text { Government specific } \\
\text { policies. }\end{array}$} \\
\hline $\begin{array}{c}\text { Article } \\
2 \mathrm{~A}\end{array}$ & $\nabla$ & $\begin{array}{l}\text { Paragraph 2: State assets in the form of state- } \\
\text { owned shares in state-owned enterprises, as } \\
\text { referred to in Article 2(2) part d, shall be used as } \\
\text { state-owned capital participation in other state- } \\
\text { owned enterprises in such a way that most of the } \\
\text { shares are owned by other state-owned } \\
\text { enterprises, such state-owned enterprises shall } \\
\text { become state-owned enterprise subsidiaries, } \\
\text { provided that the state is required to have shares } \\
\text { with special rights stipulated in the articles of } \\
\text { association. } \\
\text { Explanation of Paragraph 2: Regulated } \\
\text { privileges in the articles of association is the } \\
\text { right to approve: a. Appointment of the Board of } \\
\text { Directors and Commissioners; b. Changes in the } \\
\text { articles of association; c. Changes in the } \\
\text { ownership structure of shares; d. merger, } \\
\text { separation and disjunction, as well as takeovers } \\
\text { by other companies. } \\
\text { Paragraph 7: State-owned enterprise subsidiaries } \\
\text { as referred to in paragraph (2) shall be treated in } \\
\text { the same way as state-owned enterprises on the } \\
\text { following issues: a. Obtain government } \\
\text { assignments or perform public services; and/or } \\
\text { b. Obtain country-specific policies and/or } \\
\text { government policies, including in the } \\
\text { management of natural resources, with some } \\
\text { treatment as applied to state-owned enterprises. }\end{array}$ & \\
\hline
\end{tabular}

Source: Government Regulation (PP) Number 72 of 2016, the data is processed by researchers

With reference to the letter of the Ministry of State-owned Enterprises of the Republic of Indonesia Number S14/D3.MBU.1/06/2019 on 21 June 2019 that Public Enterprise for Banknotes Printing and Minting of the Republic of Indonesia (Perum Peruri) is appointed as the holding company for printing and media sector. And also a letter (SR-394/MBU/06/2019) from the Ministry of State-owned Enterprises, which showed the Ministry of Finance a plan to set up a printing and media holding, the content of which was to implement the 2014-2019 Roadmap in order to make state-owned companies more effective as agents of development, the establishment of a state-owned enterprise holding has become one of the strategic initiatives of the Ministry of State-owned Enterprises. By forming a holding company, state-owned printing and media companies are expected to become larger and more agile, through increased competitiveness, accelerated sustainable development and integrated synergy, through a scheme to transfer ownership of state-owned companies to equity.

The process of forming a printing and media holding must be seen from the Government Regulation or the purpose of establishing a business which is included in the Government Regulation of the five state-owned printing and media companies which is merged in a printing and media holding, that then gives two holding choices or grouped into two clusters by the Ministry of State-owned Enterprises and an independent consultant, i.e. State printing security cluster and media cluster. The State printing security cluster, Public 
Enterprise for Banknotes Printing and Minting of the Republic of Indonesia (Perum Peruri) oversees the Government Printing Office of the Republic of Indonesia (Perum PNRI) and media clusters (creating news and non-news content), i.e. Antara National News Agency (Perum LKBN Antara), PT Balai Pustaka, and the State Film Production Company (Perum PFN). Table 3 below shows the business objectives of establishing Government Regulations on Public Enterprise for Banknotes Printing and Minting of the Republic of Indonesia (Perum Peruri), the Government Printing Office of the Republic of Indonesia (Perum PNRI), the Antara National News Agency (Perum LKBN Antara), PT Balai Pustaka, and the State Film Production Company (Perum PFN):

Table 3. Scope of Business Based on Government Regulations on the Establishment of Printing Holding or State Security clusters

\begin{tabular}{|c|c|c|}
\hline $\begin{array}{l}\text { State-owned } \\
\text { Enterprises }\end{array}$ & $\begin{array}{c}\text { Public Enterprise for Banknotes } \\
\text { Printing and Minting of the Republic of } \\
\text { Indonesia (Perum Peruri) }\end{array}$ & $\begin{array}{l}\text { Government Printing Office of the } \\
\text { Republic of Indonesia (Perum } \\
\text { PNRI) }\end{array}$ \\
\hline Legal basis & $\begin{array}{l}\text { Government Regulation No. } 6 \text { of } 2019 \text { - } \\
\text { Article } 10 \text { Paragraph } 1\end{array}$ & $\begin{array}{l}\text { Government Regulation No. } 72 \text { of } \\
2012 \text { - Article } 6 \text { Paragraph } 1\end{array}$ \\
\hline $\begin{array}{l}\text { Business } \\
\text { objectives }\end{array}$ & $\begin{array}{l}\text { Carry out and support government policies } \\
\text { and programs in the field of economy and } \\
\text { national growth by organizing businesses } \\
\text { aimed at public service obligations in the } \\
\text { form of providing Indonesian Rupiah- } \\
\text { related goods or services, rendering state } \\
\text { documents with high-security features and } \\
\text { optimizing company resource utilization. }\end{array}$ & $\begin{array}{l}\text { Carry out government assignments in } \\
\text { the field of printing and } \\
\text { dissemination of state documents, } \\
\text { and conduct business in the field of } \\
\text { public printing, such as printing } \\
\text { security, publishing, multimedia, and } \\
\text { graphic services. }\end{array}$ \\
\hline Legal basis & $\begin{array}{l}\text { Government Regulation No. } 6 \text { of } 2019 \text { - } \\
\text { Article } 10 \text { Paragraph } 2\end{array}$ & $\begin{array}{l}\text { Government Regulation No. } 72 \text { of } \\
2012 \text { - Article } 6 \text { Paragraph } 2\end{array}$ \\
\hline Business scope & $\begin{array}{l}\text { 1. Print rupiah currency to meet needs, } \\
\text { as demanded by Bank Indonesia } \\
\text { 2. Make a state document that has } \\
\text { security features in the form of } \\
\text { immigration documents and stamped } \\
\text { objects } \\
\text { 3. Making other documents for countries } \\
\text { that have security features in the form } \\
\text { of excise tapes and defense documents } \\
\text { 4. Digital security services } \\
\text { 5. Manufacturing of banknotes, security } \\
\text { paper, and security ink } \\
\text { 6. Providing services that have security } \\
\text { features } \\
\text { 7. Printing money and making } \\
\text { documents of other countries that } \\
\text { have security features at the request of } \\
\text { the country concerned } \\
\text { 8. Making other documents for countries } \\
\text { that have security features and non- } \\
\text { metal minting goods }\end{array}$ & $\begin{array}{l}\text { 1. Government assignments in the } \\
\text { field of printing and } \\
\text { dissemination of state documents } \\
\text { 2. Print ATM cards, debit cards, } \\
\text { credit cards, and smart cards } \\
\text { 3. Printing security documents and } \\
\text { general election documents } \\
\text { 4. Issuance of other graphic } \\
\text { services } \\
\text { 5. Document solution information }\end{array}$ \\
\hline
\end{tabular}

Source: Government Regulation No. 6 of 2019 concerning Public Enterprise for Banknotes Printing and Minting of the Republic of Indonesia (Perum Peruri) and Government Regulation No. 72 of 2012 concerning the Government Printing Office of the Republic of Indonesia (Perum PNRI) 
Table 4. Scope of Business Based on Government Regulations on the establishment of media holding or media cluster

\begin{tabular}{|c|c|c|c|}
\hline $\begin{array}{c}\text { State-owned } \\
\text { Enterprises }\end{array}$ & $\begin{array}{c}\text { Antara National News } \\
\text { Agency (Perum LKBN } \\
\text { Antara) }\end{array}$ & PT Balai Pustaka & $\begin{array}{l}\text { State Film Production } \\
\text { Company (Perum PFN) }\end{array}$ \\
\hline Legal basis & $\begin{array}{l}\text { Government Regulation No. } \\
40 \text { of } 2007 \text { - Article } 6 \\
\text { Paragraph } 1\end{array}$ & $\begin{array}{l}\text { Government Regulation } \\
\text { No. } 6 \text { of } 1996 \text { - Article } 2 \\
\text { Paragraph } 1\end{array}$ & $\begin{array}{l}\text { Government Regulation } \\
\text { No. } 5 \text { of } 1988 \text { - Article } 5 \\
\text { Paragraph } 2\end{array}$ \\
\hline $\begin{array}{l}\text { Business } \\
\text { objectives }\end{array}$ & $\begin{array}{l}\text { Carrying out business aimed } \\
\text { at public benefit (public } \\
\text { service obligation) in the } \\
\text { form of providing goods or } \\
\text { services in the quality of the } \\
\text { press (media) at an } \\
\text { affordable price by the } \\
\text { community based on the } \\
\text { principle of sound company } \\
\text { management. }\end{array}$ & $\begin{array}{l}\text { Develop and disseminate } \\
\text { information and technology } \\
\text { through books and the } \\
\text { results of publishing and } \\
\text { other public interest } \\
\text { printing, building the } \\
\text { economy and national } \\
\text { resilience through the } \\
\text { growth of book and } \\
\text { multimedia industries } \\
\text { within the framework of } \\
\text { improving the nation's } \\
\text { intellectual life and } \\
\text { enhancing the nation's } \\
\text { culture. }\end{array}$ & $\begin{array}{l}\text { Building national } \\
\text { economy and resilience by } \\
\text { organizing film } \\
\text { production businesses and } \\
\text { film engineering services } \\
\text { businesses. }\end{array}$ \\
\hline Legal basis & $\begin{array}{l}\text { Government Regulation No. } \\
40 \text { of } 2007 \text { - Article } 6 \\
\text { Paragraph } 2\end{array}$ & $\begin{array}{l}\text { Government Regulation } \\
\text { No. } 6 \text { of } 1996 \text { - Article } 2 \\
\text { Paragraph } 2\end{array}$ & $\begin{array}{l}\text { Government Regulation } \\
\text { No. } 5 \text { of } 1988 \text { - Article } 6\end{array}$ \\
\hline $\begin{array}{l}\text { Business } \\
\text { scope }\end{array}$ & 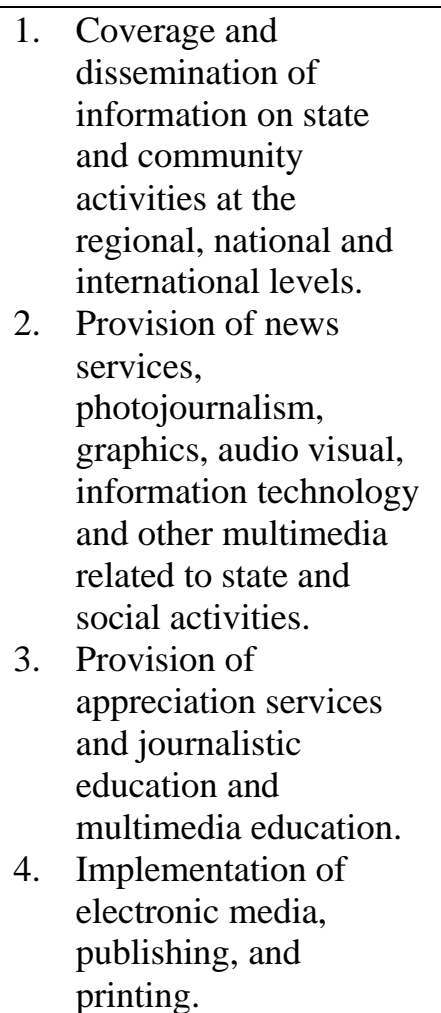 & $\begin{array}{l}\text { 1. Collection, research, } \\
\text { preservation, and } \\
\text { publishing and printing } \\
\text { of manuscripts that } \\
\text { contain noble cultural } \\
\text { values of the nation, } \\
\text { including ancient } \\
\text { manuscripts } \\
\text { 2. Book publishing and } \\
\text { printing } \\
\text { 3. Distribution and } \\
\text { marketing of books, } \\
\text { printed materials, } \\
\text { multimedia and other } \\
\text { means for education } \\
\text { and culture }\end{array}$ & $\begin{array}{ll}\text { 1. } & \text { Film production } \\
\text { 2. } & \text { Supporting } \\
& \text { filmmaking services }\end{array}$ \\
\hline
\end{tabular}

Source: Government Regulation No. 40 of 2007 concerning Antara National News Agency (Perum LKBN Antara), Government Regulation No. 6 of 1996 concerning PT Balai Pustaka, and Government Regulation No. 5 of 1988 concerning the State Film Production Company (Perum PFN) 
The process of establishing a printing and media holding involves a Government Regulation on adding capital investment as a legal basis to the holding parent. There are several provisions in the Government Regulation concerning the allocation of capital investment to the holding company: (1) Additional equity capital in the Unitary State of the Republic of Indonesia to the printing and media parent company through the transfer of all B-series shares of ownership in the Unitary State of the Republic of Indonesia in printing and media holding subsidiaries; (2) Affirmation that the Unitary State of the Republic of Indonesia still own A-series shares or dual series (special) shares in each of the printing and media holding subsidiaries and has the authority as stipulated in the articles of association of each printing and media holding subsidiary; (3) Transfer of all B-series shares ownership to printing and media holding subsidiaries that resulted in changes in the status of business entities from public companies to limited liability companies, such as the Government Printing Office of the Republic of Indonesia (Perum PNRI), the Antara National News Agency (Perum LKBN Antara), and the State Film Production Company (Perum PFN). PT Balai Pustaka has no Limited Liability Company, because the majority share of the government is not a minority share, because the government only has A-series shares or dual series shares; (4) Affirmations regarding special assignments from the Government, namely the Ministry of State-owned Enterprises, to all members of printing and media holding, both the parent company and its subsidiaries still hold special assignments in accordance with Government Regulations of each company; (5) Arrangement of mechanism for granting Public Service Obligation (PSO) funds to each printing and media holding subsidiary, whether through a holding company or can be done directly to each subsidiary (printing holding subsidiary); (6) Revocation of Government Regulation, related to Government Regulation which is no longer relevant to business conducted by Public Enterprise for Banknotes Printing and Minting of the Republic of Indonesia (Perum Peruri), the Government Printing Office of the Republic of Indonesia (Perum PNRI), the Antara National News Agency (Perum LKBN Antara), PT Balai Pustaka, and the State Film Production Company (Perum PFN), as a result of the establishment of printing holding and media. For example Government Regulation No. 72 of 2012 concerning Public Enterprise for Banknotes Printing and Minting of the Republic of Indonesia (Perum Peruri), Government Regulation No. 40 of 2007 concerning the Antara National News Agency (Perum LKBN Antara), and Government Regulation No. 5 of 1988 concerning the State Film Production Company (Perum PFN).

To date, the process of forming printing and media holding can be formed into three model options or form of holding. The first option is one holding option, i.e. printing and media holding with Public Enterprise for Banknotes Printing and Minting of the Republic of Indonesia (Perum Peruri) as the holding company and assigned to oversee four state-owned subsidiaries namely the Government Printing Office of the Republic of Indonesia (Perum PNRI), the Antara National News Agency (Perum LKBN Antara), PT Balai Pustaka, and the State Film Production Company (Perum PFN). Option two consists of two holding media, i.e. the first printing holding with Public Enterprise for Banknotes Printing and Minting of the Republic of Indonesia (Perum Peruri) as the holding company assigned to oversee a subsidiary of a stateowned company (Government Printing Office of the Republic of Indonesia/Perum PNRI) and the second holding media with Antara National News Agency (Perum LKBN Antara) as the holding company that is assigned to supervise another two state-owned subsidiaries, PT Balai Pustaka and the State Film Production Company (Perum PFN). Option three consists of one holding option, i.e. printing and media holding with Antara National News Agency (Perum LKBN Antara) as the holding company that is assigned to oversee three state-owned subsidiaries, namely Government Printing Office of the Republic of Indonesia (Perum PNRI), PT Balai Pustaka and the State Film Production Company (Perum PFN), whereas Public Enterprise for Banknotes Printing and Minting of the Republic of Indonesia (Perum Peruri) will stand alone.

Financial consolidation that can be carried out in the process of forming a stateowned printing and media holding can be done by looking at the company of scale of each holding option, which is seen in terms of assets, 
equity and liabilities owned by each company member in the previous year (in this case, the fiscal year 2018), the consolidation can be seen in the table below:

Table 5. Consolidation of Company Scale in terms of Total Assets, Total Equity, and Total Liabilities

\begin{tabular}{|c|c|c|c|c|c|}
\hline \multirow{2}{*}{$\begin{array}{c}\text { Historical } \\
\text { Asset (2018) } \\
\text { (in billion IDR) }\end{array}$} & \multirow{2}{*}{$\begin{array}{c}\text { Option 1 } \\
\text { Printing and } \\
\text { media } \\
\text { holding }\end{array}$} & \multicolumn{2}{|c|}{ Option 2} & \multicolumn{2}{|c|}{ Option 3} \\
\hline & & $\begin{array}{l}\text { Printing } \\
\text { holding }\end{array}$ & $\begin{array}{l}\text { Media } \\
\text { holding }\end{array}$ & $\begin{array}{c}\text { Public Enterprise for } \\
\text { Banknotes Printing } \\
\text { and Minting of the } \\
\text { Republic of } \\
\text { Indonesia (Perum } \\
\text { Peruri) }\end{array}$ & $\begin{array}{l}\text { Printing and media } \\
\text { holding }\end{array}$ \\
\hline $\begin{array}{c}\text { Public } \\
\text { Enterprise for } \\
\text { Banknotes } \\
\text { Printing and } \\
\text { Minting of the } \\
\text { Republic of } \\
\text { Indonesia } \\
\text { (Perum Peruri) }\end{array}$ & $5,055.3$ & $5,055.3$ & & $5,055.3$ & \\
\hline $\begin{array}{c}\text { Antara } \\
\text { National News } \\
\text { Agency (Perum } \\
\text { LKBN Antara) }\end{array}$ & 215.3 & & 215 & & 215 \\
\hline $\begin{array}{l}\text { Government } \\
\text { Printing Office } \\
\text { of the Republic } \\
\text { of Indonesia } \\
\text { (Perum PNRI) }\end{array}$ & 617.3 & 617.3 & & & 617.3 \\
\hline $\begin{array}{l}\text { PT Balai } \\
\text { Pustaka }\end{array}$ & 311.3 & & 311 & & 311 \\
\hline $\begin{array}{l}\text { State Film } \\
\text { Production } \\
\text { Company } \\
\text { (Perum PFN) }\end{array}$ & 41.8 & & 41.8 & & 41.8 \\
\hline Total Asset & 6,241 & $5,672.6$ & 568.4 & $5,055.3$ & $1,185.7$ \\
\hline
\end{tabular}

\begin{tabular}{|c|c|c|c|c|c|}
\hline \multirow{2}{*}{$\begin{array}{c}\text { Historical } \\
\text { Equity (2018) } \\
\text { (in billion IDR) }\end{array}$} & \multirow{2}{*}{$\begin{array}{l}\text { Option 1 } \\
\text { Printing and } \\
\text { media } \\
\text { holding }\end{array}$} & \multicolumn{2}{|c|}{ Option 2} & \multicolumn{2}{|c|}{ Option 3} \\
\hline & & $\begin{array}{l}\text { Printing } \\
\text { holding }\end{array}$ & $\begin{array}{l}\text { Media } \\
\text { holding }\end{array}$ & $\begin{array}{l}\text { Public Enterprise for } \\
\text { Banknotes Printing } \\
\text { and Minting of the } \\
\text { Republic of } \\
\text { Indonesia (Perum } \\
\text { Peruri) }\end{array}$ & $\begin{array}{l}\text { Printing and media } \\
\text { holding }\end{array}$ \\
\hline $\begin{array}{c}\text { Public } \\
\text { Enterprise for } \\
\text { Banknotes } \\
\text { Printing and } \\
\text { Minting of the } \\
\text { Republic of } \\
\text { Indonesia } \\
\text { (Perum Peruri) }\end{array}$ & $2,514.1$ & $2,514.1$ & & $2,514.1$ & \\
\hline $\begin{array}{c}\text { Antara } \\
\text { National News }\end{array}$ & 52.8 & & 53 & & 53 \\
\hline
\end{tabular}




\begin{tabular}{|c|c|c|c|c|c|}
\hline $\begin{array}{c}\text { Agency (Perum } \\
\text { LKBN Antara) }\end{array}$ & 181 & 181 & & & 181 \\
\hline $\begin{array}{c}\text { Government } \\
\text { Printing Office } \\
\text { of the Republic } \\
\text { of Indonesia } \\
\text { (Perum PNRI) }\end{array}$ & & & & & \\
\hline $\begin{array}{c}\text { PT Balai } \\
\text { Pustaka }\end{array}$ & 119.4 & & 119 & & 119 \\
\hline $\begin{array}{c}\text { State Film } \\
\text { Production } \\
\text { Company } \\
\text { (Perum PFN) }\end{array}$ & 20.6 & & 20.6 & & 20.6 \\
\hline Total Equity & $\mathbf{2 , 8 8 7 . 9}$ & $\mathbf{2 , 6 9 5 . 1}$ & $\mathbf{1 9 2 . 8}$ & $\mathbf{2 , 5 1 4 . 1}$ & \\
\hline
\end{tabular}

\begin{tabular}{|c|c|c|c|c|c|}
\hline \multirow{2}{*}{$\begin{array}{l}\text { Historical } \\
\text { Liabilities } \\
\text { (2018) (in } \\
\text { billion IDR) }\end{array}$} & \multirow{2}{*}{$\begin{array}{c}\text { Option 1 } \\
\text { Printing and } \\
\text { media } \\
\text { holding }\end{array}$} & \multicolumn{2}{|c|}{ Option 2} & \multicolumn{2}{|c|}{ Option 3} \\
\hline & & $\begin{array}{l}\text { Printing } \\
\text { holding }\end{array}$ & $\begin{array}{l}\text { Media } \\
\text { holding }\end{array}$ & $\begin{array}{c}\text { Public Enterprise for } \\
\text { Banknotes Printing } \\
\text { and Minting of the } \\
\text { Republic of } \\
\text { Indonesia (Perum } \\
\text { Peruri) }\end{array}$ & $\begin{array}{l}\text { Printing and media } \\
\text { holding }\end{array}$ \\
\hline $\begin{array}{c}\text { Public } \\
\text { Enterprise for } \\
\text { Banknotes } \\
\text { Printing and } \\
\text { Minting of the } \\
\text { Republic of } \\
\text { Indonesia } \\
\text { (Perum Peruri) }\end{array}$ & $2,514.1$ & $2,514.1$ & & $2,514.1$ & \\
\hline $\begin{array}{c}\text { Antara } \\
\text { National News } \\
\text { Agency (Perum } \\
\text { LKBN Antara) }\end{array}$ & 163 & & 163 & & 163 \\
\hline $\begin{array}{l}\text { Government } \\
\text { Printing Office } \\
\text { of the Republic } \\
\text { of Indonesia } \\
\text { (Perum PNRI) }\end{array}$ & 436.3 & 436.3 & & & 436.3 \\
\hline $\begin{array}{l}\text { PT Balai } \\
\text { Pustaka }\end{array}$ & 191.9 & & 192 & & 192 \\
\hline $\begin{array}{c}\text { State Film } \\
\text { Production } \\
\text { Company } \\
\text { (Perum PFN) }\end{array}$ & 21.2 & & 21.2 & & 21.2 \\
\hline Total Equity & $3,353.5$ & $2,977.4$ & 376.1 & $2,541.1$ & 812.4 \\
\hline
\end{tabular}

Source: The financial statements of each state-owned enterprises

The consolidated financial statements of printing and media holding can be seen from the side of the company of scale of each printing and media holding option, i.e. total assets, total equity and total liabilities in 2018. Hence, the one with the largest holding scale is option one i.e. printing and media holding, because it covers the entire company (members of printing and media holding), namely Public Enterprise for Banknotes Printing and Minting of the Republic of Indonesia (Perum Peruri), the Government Printing Office of the Republic 
of Indonesia (Perum PNRI), the Antara National News Agency (Perum LKBN Antara), PT Balai Pustaka, and the State Film Production Company (Perum PFN), with a relatively high total accumulated asset value of IDR 6,241 billion and total equity of IDR 2,888 billion. But it has a relatively high value of debt accumulation (liabilities) of IDR 3,353.5. It has the possibility on placing a burden to the holding company to indemnify the debt owned by four companies, i.e., the Government Printing Office of the Republic of Indonesia (Perum PNRI), the Antara National News Agency (Perum LKBN Antara), PT Balai Pustaka, and the State Film Production Company (Perum PFN).

The accumulated value of the two option holding assets, namely the printing holding (Public Enterprise for Banknotes Printing and Minting of the Republic of Indonesia (Perum Peruri) holding), is relatively high with an accumulated total asset value of IDR 5,673 billion and total equity of IDR 2,695 billion, but has a relatively high value of debt accumulation (liabilities) of IDR 2,977.4 billion. But the parent company (Public Enterprise for Banknotes Printing and Minting of the Republic of Indonesia (Perum Peruri) may only endure the debt of one company (Perum PNRI) which has a relatively low debt value of IDR 436.3 billion. While the accumulated value of media holding assets is relatively low, because it has a total asset of IDR 568 billion and total equity of IDR 193 billion, and has a relatively low debt accumulation value of IDR 376.1 billion. So that the parent company, Antara National News Agency (Perum LKBN Antara) is not overburden with the debts of the two companies, namely the debt owned by PT Balai Pustaka and the debt owned by State Film Production Company (Perum PFN).

The accumulated value of option three assets, namely printing and media holding (the Antara National News Agency (Perum LKBN Antara)) is relatively moderate, because it has an accumulated total asset value of IDR 1,186 billion and total equity of IDR 374 billion. But it has a relatively high value of debt accumulation (liabilities) in the amount of IDR 812.4 billion. So that the parent company, the Antara National News Agency (Perum LKBN Antara), must endure the debts of three companies (the Government Printing Office of the Republic of Indonesia (Perum PNRI), PT Balai Pustaka, and State Film Production Company (Perum PFN)). Whereas the standalone company, Public Enterprise for Banknotes Printing and Minting of the Republic of Indonesia (Perum Peruri), has relatively high asset value, with total assets of IDR 5,055 billion and total equity of IDR 2,514 billion. But it has a relatively high debt value of IDR 2,541.1 billion.

In terms of the company of scale, option two can be an option for a model or form of printing and media holding with two holding options: printing holding and media holding, because it has a relatively high value of total asset accumulation and total equity and relatively low debt accumulation, therefore this condition may not overburden the holding company.

In the process of forming a printing and media holding, the Ministry of State-owned Enterprises as the capital owner provides a follow-up policy of forming two holding companies, the first is printing holding and second is holding media, so printing holding is Public Enterprise for Banknotes Printing and Minting of the Republic of Indonesia (Perum Peruri) which will oversee Government Printing Office of the Republic of Indonesia (Perum PNRI) and holding media which will be the lead is Antara National News Agency (Perum LKBN Antara) which will oversee PT Balai Pustaka and State Film Production Company (Perum PFN). The steps that must be taken in the process of forming a printing holding and holding media are almost the same as the process of forming a printing holding and media, namely first to conduct a feasibility study by appointing an independent consultant to study the formation of printing and media holding, and, secondly, to conduct a process of reviewing the changes of the entity in the form of a public company into a business entity in the form of a Limited Liability Company, the three Ministry of State-owned Enterprises must conduct a study with the Ministry of Finance related to changes in the business entity in the form of a public company into a business entity in the form of a Limited Liability Company, in accordance with Government Regulations No. 77 of 2009 concerning adding capital participation of the Unitary State of the 
Republic of Indonesia into the share capital of Limited Liability Company or public company to manage the company's assets, the four most difficult steps to take are legality and operations, and finally is the allocation of Human Resources (HR) or the unification of the HR culture of each company into a media holding and media holding.

The process of forming a printing and media holding can be developed into three options or three forms of holding initiatives, the first option is printing and media holding with Public Enterprise for Banknotes Printing and Minting of the Republic of Indonesia (Perum Peruri) as the holding company that will oversee four companies, namely Government Printing Office of the Republic of Indonesia (Perum PNRI), the Antara National News Agency (Perum LKBN Antara), PT Balai Pustaka, and the State Film Production Company (Perum PFN). The second option is printing and media holding in which Public Enterprise for Banknotes Printing and Minting of the Republic of Indonesia (Perum Peruri) is assigned to oversee one company, namely Government Printing Office of the Republic of Indonesia (Perum PNRI), whereas Antara National News Agency (Perum LKBN Antara) becomes the holding parent of media holding that is assigned to oversee two companies, i.e. PT Balai Pustaka and PFN Public Corporation. The third option is the printing and media holding company with Antara National News Agency (Perum LKBN Antara) which is the holding company that should oversee three companies, namely Government Printing Office of the Republic of Indonesia (Perum PNRI), PT Balai Pustaka, and State Film Production Company (Perum PFN). While Public Enterprise for Banknotes Printing and Minting of the Republic of Indonesia (Perum Peruri) settled as a stand-alone organization. So option two is the most appropriate option in a logical roadmap and holding characteristics because the printing business (security printing) and the media business (distribution news) are two different businesses.

\section{Conclusion}

The process of establishing printing and media holdings has been carried out on the basis of the existence of shareholder action to perform the efficiency of state-owned companies with similar tasks, business sectors or even objectives. The printing and media business sector has been discussed in the study. In conjunction with the Master Plan for Revitalization of State-owned Enterprises 2005-2009, Presidential Instruction No. 5 of 2008, the 2009-2014 Masterplan for acceleration, expansion and economic development, and in accordance with the 20152019 strategic plan and roadmap of the Ministry of State-owned Enterprises of the Republic of Indonesia in 2014-2019, one of the contents is to continue the concept of National Holding Company.

The feasibility study of printing and media holding is seen from three aspects, namely business aspects, legal aspects, and financial aspects. Business aspects in the process of forming a printing and media holding must have a business synergy between members of the printing holding and the media that can produce value-added creation. Legal aspects of the printing and media holding discussed the fact that there must be a Government Regulation on the establishment of printing and media holdings, a Government Regulation on capital equity in a holding company, including equity capital in a public company, and a Government Regulation on changes in the form of business entities of public companies into business entities in the form of Limited Liability Company. The financial aspect in the process of forming a printing and media holding is the financial performance of each printing and media holding company member is measured using the company of scale or total assets and the total equity of each printing and media holding company member.

The results of this study are expected to be used by companies and governments as one of the reference materials and references in the process of forming printing and media holding as well as lessons learned in making other holds, and this research is expected to provide references and benefits in the fields of economics and business, especially in management accounting studies that can be used as reference material in wider research.

There are several weaknesses in this study. The research design is difficult to replicate for research in other locations, there is still lack of participation of participants or 
informants in the study, and the unclear arguments and policies of the government as the capital owner. Related to suggestions for further research is research conducted in different places, adding theories that are relevant to the process of forming a holding, and used for broader research related to the process of forming a holding company

\section{References}

Ayudya, A. C., \& Wibowo, A. (2018). The Intention to Use E-Money using Theory of Planned Behavior and Locus of Control. Jurnal Keuangan Dan Perbankan, 22(2), 335-349. https://doi.org/10.26905/jkdp.v22i2.1691

Bashori, K. (2018). Pendidikan Politik di Era Disrupsi. Sukma: Jurnal Pendidikan, 2(2), 287-310. https://doi.org/10.32533/02207.2018

Christensen, C. M., Raynor, M. E., Rory, M., \& McDonald, R. (2015). What is disruptive innovation. Harvard Business Review, 93(12), 44-53. https://doi.org/10.1353/abr.2012.0147

Dimaggio, P. J., \& Powell, W. W. (2012). GRIMALDI Evolution of the Insects.pdf. American Sociological Review, 48(2), 147-160.

Hamdan, H. (2018). Industri 4.0: Pengaruh Revolusi Industri Pada Kewirausahaan Demi Kemandirian Ekonomi. Jurnal Nusantara Aplikasi Manajemen Bisnis, $3(2), 1$. https://doi.org/10.29407/nusamba.v3i2.1 2142

Harminingtyas, R. (2010). Manajeme Perubahan. Jurnal STIE Semarang, Vol. 2, pp. 76-83.

Heriyanto. (2018). College Academic Freedom In The Digital Disruption Era. Jurnal Vijjacariya, 5(1), 21-35.

Jay, B. (1991). firm Resources and Sustained Competitive. Journal of Management. Vol 17, No 1,99-120.
Kaminski, J. (2011). Theory applied to informatics-Lewin's change theory. Canadian Journal of Nursing Informatics, 6(1).

Karman. (2017). Disruptif Teknologi Internet Dan Eksistensi Media Cetak Internet Technology Disruption and the Print Media Exictence. Jurnal Kementerian Komunikasi Dan Informatika, Direvisi(9), 12-12.

Kitchen, P. J., \& Daly, F. (2002). Internal communication during change management. Corporate Communications: An International Journal, 7(1), 46-53. https://doi.org/10.1108/13563280210416 035

Matthew, M. B., Michael, H. A., \& Johnny, S. (2014). Qualitative Data Analysis

Meyer, J. M. (2007). Reflections on Institusional Theories of Organizations. The SAGE handbook of organizational institusionalism: Sage Publ., ISBN 9781412931236-Ch34. 1-22.

Pangaribuan, C. H., \& Kawiworo, J. (2019). Review Volume, Consumer Ratings, and Rental Price in the Sharing Economy: The Case of Airbnb Jakarta. Ekonomi Dan Bisnis, 6(1), 72. https://doi.org/10.35590/jeb.v6i1.814

Permanasari, Y. W., \& Surya Perdhana, M. (2017). PROSES TRANSFORMASI PT. POS INDONESIA (Studi Kasus Pada Kantor Processing Centre Semarang). Diponegoro Journal of Management, 6 , $1-13$.

Prasetya, D. N., \& Siti, M. (2011). Analisis Pengaruh Intellectual Capital Terhadap Islamicity Financial Performance Index Bank Syariah Di Indonesia. 1-28.

Prihatin, R. B. (2016). Dampak Sosial Transportasi Berbasis Online. Majalah Info Singkat Kesejahteraan Sosial: Kajian Singkat Terhadap Isu Aktual Dan Strategis, VIII(07), 9-12. 
Purnomo, R. (2011). Resource-Based View dan Keunggulan Bersaing

Berkelanjutan : Sebuah Telaah Kritis

Terhadap Pemikiran Jay Barney ( 1991 ).

Proceeding Seminar Nasional \& Call

For Papers (SCA-1), (1), 1-16. Retrieved from jp.feb.unsoed.ac.id

Putra, N. A., \& Gede, D. S. (2019). I Nyoman Andy Putra Bali dan Gede Sri Darma, 2019. 16(2), 1-13.

Sekaran, U., \& Bougie, R. (2016). Reserach Methods for Bussiness A Skill-Bulding Approach. 1-447.

Sigar, J. F. (2016). the Influence of Perceived Usefulness, Perceived Ease of Use and Perceived Enjoyment To Intention To Use Electronic Money in Manado. Jurnal Riset Ekonomi, Manajemen, Bisnis Dan Akuntansi, 4(2), 498-507.

Sijabat, R. (2019). Sharing economy: a study on the factors influencing users' motivation to use ride sharing platforms. 14(1), 65-87.

Utami, N. S. (2018). Analisa kinerja sektor ritel indonesia. Ecopreneur, 1(1), 43-48.

Wernerfelt, B. (1984). Harmonized implementation of Application-Specific Messages (ASMs). Strategic Management Journal, CINCO(2), 1-12. https://doi.org/10.1002/smj.4250050207

Widyaningdyah, A. U., \& Aryani, Y. A. (2013). Intellectual Capital dan Keunggulan Kompetitif (Studi Empiris Perusahaan Manufaktur versi Jakarta Stock Industrial Classification-JASICA). Jurnal Akuntansi Dan Keuangan, 15(1), 1-14. https://doi.org/10.9744/jak.15.1.114 